\title{
New Records of Marine Macroalgae on the Caribbean on Coast of Costa Rica
}

\author{
Rubén Cabrera ${ }^{1 *}$, Jhoana Díaz-Larrea², Schery Umanzor ${ }^{3}$ \\ ${ }^{1}$ Gabinete de Arqueología, Oficina del Historiador de la Ciudad, Habana Vieja, Cuba \\ ${ }^{2}$ Departamento de Hidrobiología, Universidad Autónoma Metropolitana-Iztapalapa, Ciudad de México, México \\ ${ }^{3}$ Department of Ecology \& Evolutionary Biology, University of Connecticut, Stamford, CT, USA \\ Email: *cabreraalgas@gmail.com, jhoanadiazl@gmail.com, schery.umanzor@uconn.edu
}

How to cite this paper: Cabrera, R., Díaz-Larrea, J. and Umanzor, S. (2019) New Records of Marine Macroalgae on the Caribbean on Coast of Costa Rica. American Journal of Plant Sciences, 10, 1708-1728. https://doi.org/10.4236/ajps.2019.1010122

Received: September 9, 2019

Accepted: October 11, 2019

Published: October 14, 2019

Copyright (c) 2019 by author(s) and Scientific Research Publishing Inc. This work is licensed under the Creative Commons Attribution International License (CC BY 4.0).

http://creativecommons.org/licenses/by/4.0/

\begin{abstract}
The results obtained in this study highlight that further the macroalgae diversity in this region is even higher than what is reported to date. Here we present eight new records of marine macroalgae collected from the Caribbean coast of Costa Rica between March 2011 and May 2019. The morphological characteristics of Bryocladia cuspidata, Ceratodictyon variabile, Gracilaria hayi, Padina boergesenii, Zonaria tournefortii, Sargassum furcatum, Chaetomorpha aerea, and Bryopsis pennata var. secunda are described. The genera Bryocladia and Zonaria are reported for the first time for this region.
\end{abstract}

\section{Keywords}

New Records, Caribbean Sea, Costa Rica

\section{Introduction}

The Caribbean coast of Costa Rica has an extension of approximately $215 \mathrm{~km}$, ranging from Punta Castilla in the north to Punta Mona in the south. Its coastline is straighter and less rugged than the Pacific coast counterpart [1], providing a great diversity of marine ecosystems where macroalgal meadows form distinct habitats. The Atlantic coast is the more studied and the more diverse of the two coastlines. More than 350 species are reported in the Caribbean of Costa Rica, while for the Pacific coast have been reported around of 170 species of macroalgae, of which approximately 45 are shared with the Caribbean [2]. As ecosystem engineers and primary producers, macroalgae are key in structuring their local community and maintaining functional dynamics in coastal systems [3] [4] [5]. 
From a taxonomic standpoint, the first studies of macroalgae in the Caribbean coast of Costa Rica were done by [6]-[11], who reported the first species of benthic macroalgae for the region. Further systematic studies by [12] [13] [14] were not only limited to the description of species but also included data related to the ecology and distribution of macroalgae. Later, [15] described a new species within the order Gelidiales, while [16] [17] added several new records for this region, including species within the orders Cladophorales, Bryopsidales, Fucales, Ceramiales and Nemaliales. More recently, [18] described four new species in the genus Lobophora for Costa Rica, three being described for the Caribbean coast. It is noteworthy that the most comprehensive reports compiling the list of all macroalgae and cyanophytes species described for both the Pacific and Caribbean coast of Costa Rica to date are those by [19] [20]. Their publications included data from the collection sites, as well as information about the distribution of the species along both coasts.

In the past few decades, the Caribbean coast of Costa Rica, particularly in the vicinity of Puerto Viejo, Puerto Limón and Moín have been subjected to intense anthropogenic disturbances [21], such as increased urbanization, inappropriate wastewater management and an over-exploitation of marine resources [22]. Recent data obtained by [4] showed that urban development, particularly of jetties and restaurants built facing the beach, coupled with illegal sewage systems, are threatening benthic biodiversity significantly. Despite the ecological relevance of macroalgae and the increasing pressure to which they are exposed to, their diversity and interactions along the Caribbean coast of Costa Rica are still largely unexplored. The greatest sampling efforts have been conducted along the intertidal and subtidal areas within the Cahuita National Park [17], where the reef sites have been the most studied [19]. Other areas such as Puerto Limón, Moín, and Punta Mona have rarely been explored in terms of their algal diversity. Here we report and provide diagnostic characters of seven new macroalgal records collected from underexplored sites of the Caribbean coast of Costa Rica. We also provide comparisons between these new records and related taxa. This report strengthens our knowledge about the high marine biodiversity in Costa Rica.

\section{Materials and Methods}

Sample collections were conducted in Punta Cahuita ( $\left.9^{\circ} 4^{\prime} 19.0^{\prime \prime}, 82^{\circ} 27^{\prime} 37.9^{\prime \prime}\right)$, Puerto Viejo ( $\left.9^{\circ} 65^{\prime} 86^{\prime \prime}, 82^{\circ} 75^{\prime} 51^{\prime \prime}\right)$, Playa Cocles $\left(9^{\circ} 64^{\prime} 99.8^{\prime \prime}, 82^{\circ} 73^{\prime} 03.4^{\prime \prime}\right)$, Punta Uva (9 $\left.63^{\prime} 95.5^{\prime \prime}, 82^{\circ} 69^{\prime} 66.7^{\prime \prime}\right)$, and Manzanillo (9 $\left.63^{\prime} 65.7^{\prime \prime}, 82^{\circ} 65^{\prime} 23.4^{\prime \prime}\right)$ from March to June, 2011 and January to May, 2019 (Figure 1). Collections were focused only on benthic samples. Macroalgae were collected either through SCUBA diving or from the rocky intertidal zone. After collection, samples were preserved in $4 \%$ formalin for morphological assessments. Cross sections for all samples were made using stainless steel razor blades.

Macroalgal sketches were created using a lucid camera attached to an Olympus SZH microscope. Sketches were edited using Photoshop CS3 (Adobe Systems). Voucher specimens were deposited in the Herbarium of the University of 


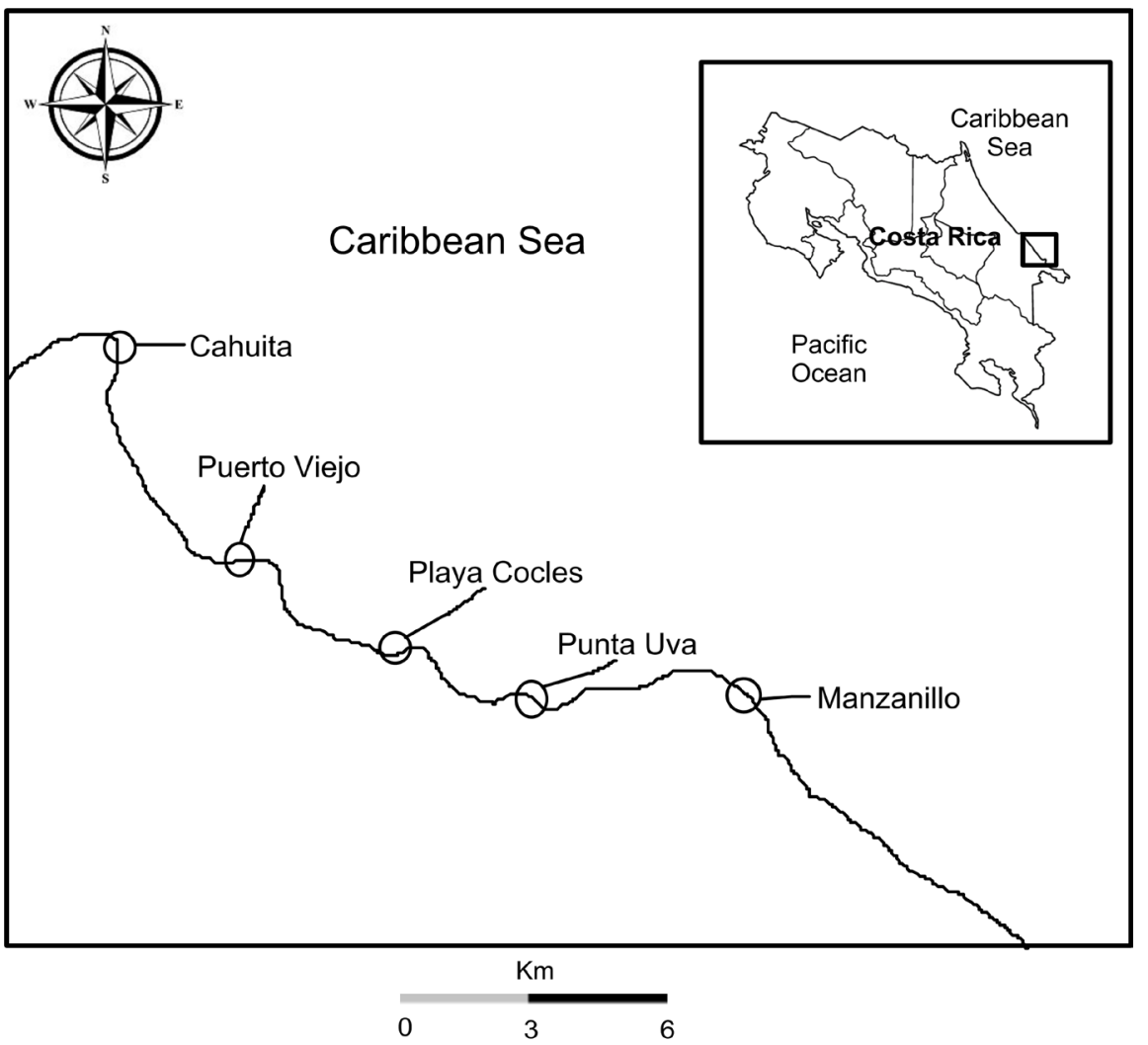

Figure 1. Sampling sites along the Caribbean coast of Costa Rica, Central America.

Michigan, (MICH), Ann Arbor, MI, United States. The taxonomic classification used is in accordance with [23] [24].

\section{Results}

The eight species identified were classified within six families: Rhodomelaceae (1), Lomentariaceae (1), Dictyotaceae (2), Sargassaceae (1), Cladophoraceae (1), and Bryopsidaceae, and (1). These records bring the total number to 332 exclusive macroalgal species reported for the Caribbean coast of Costa Rica.

Phylum: RHODOPHYTA

Class: Florideophyceae

Family Gracilariaceae

Gracilaria hayi Gurgel, Fredericq \& Norris. Tax. Econ. Seaweeds ... 9. 2004: 178.

Figure 2(1-2).

Type locality: Panama, Galeta Point [27].

Specimen studied: Voucher MICH: 1210815, 1210816.

Notes: There were reproductive structures.

Habitat: plants of shallow water and from moderately sheltered locations. Found from 0.3 to $1.5 \mathrm{~m}$ deep.

Distribution recorded in Costa Rica: Puerto Limon, Manzanillo, province of Limón. 

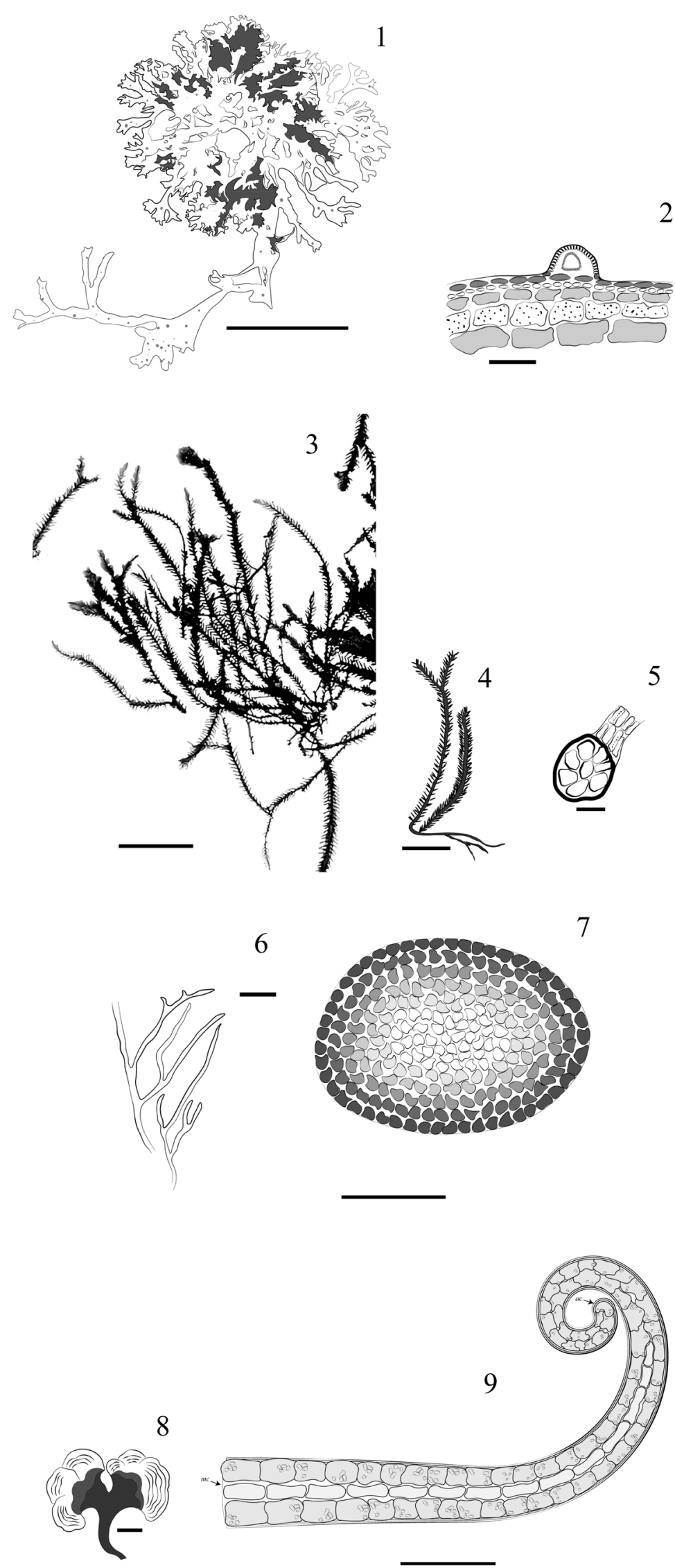

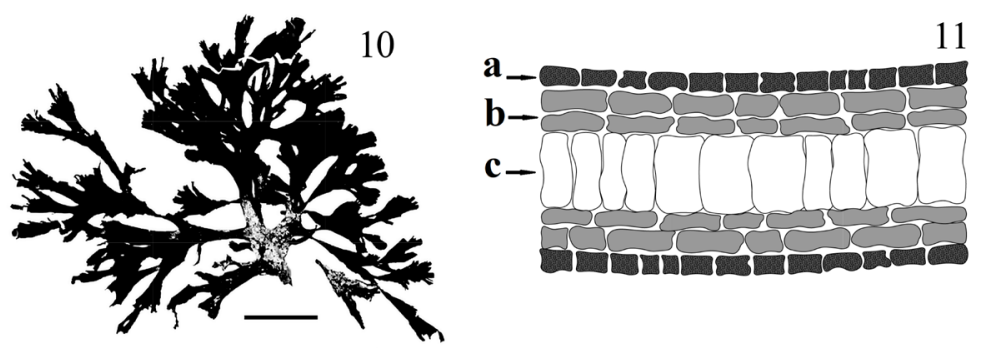

12

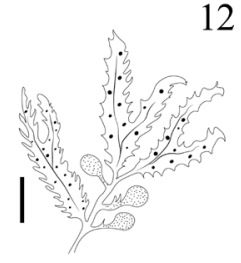

13
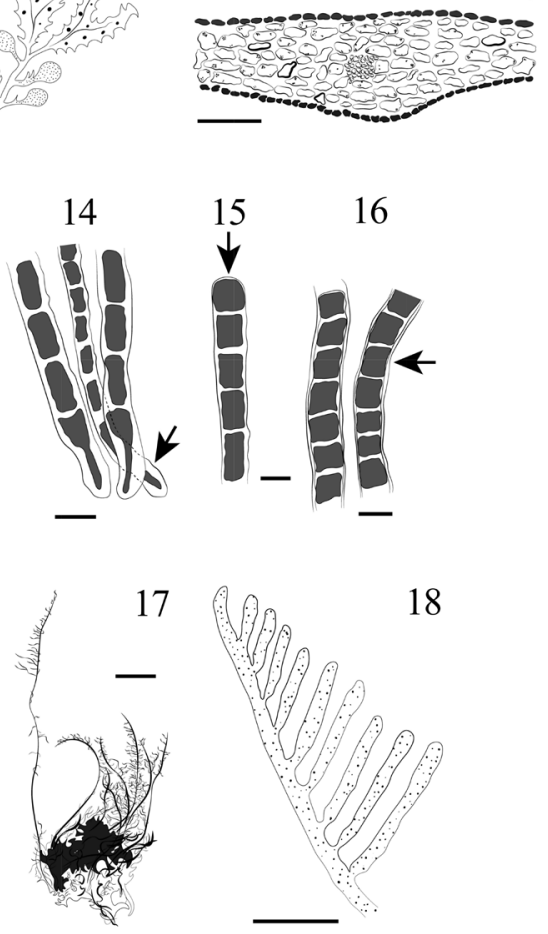

18

Figure 2. 1-2. Gracilaria hayi. 1 mature plant with cystocarps, 2 transection of cystocarp. 3-5. Bryocladia cuspidata. 3 habit of a few branches, 4 thallus wiht creeping prostrate runners, 5 transverse section of branch showing 8 pericentral cells surrounding central filaments. 6-7. Ceratodictyon variabile. 6 part of a plant with narrow prostrate and erect branches, 7 transverse section of a mature region of an erect branch in which the central medullary cells are approximately the same diameter as the surrounding inner cortical cells. 8-9. Padina boergesenii. 8 habit, 9 transverse section of the middle section $(\mathrm{mc})$ medular cell (ac) apical cell. 10-11. Zonaria tournefortii. 10 habit of mature thallus with split blades, 11 transverse section of old blade, usually 2 cortical cells overlie each medullary cell tier (a) cortical cells, (b) medullary cell, (c) other cell layers. 12-13. Sargassum furcatum. 12 general view of thallus, 13 transverse section of a blade showing midrib cells, 14-16. Chaetomorpha aerea. 14 basal portion of the thallus forming tuft, basal cell with greater elongation, 15 apical cell (arrow), 16 medians cells of the filament showing intercalary division (arrow). 17-18. Bryopsis pennata var. secunda. 17 habit, 18 frond showing unilateral branching. Scale bars [1] $=2.5 \mathrm{~cm}$, Scale bars [2] $=250 \mu \mathrm{m}$, Scale bars $[3]=12 \mathrm{~mm}$, Scale bars $[4,6,17]=5 \mathrm{~mm}$, Scale bars $[5,7,11]=100 \mu \mathrm{m}$, Scale bars $[8,10$, $12]=1 \mathrm{~cm}$, Scale bars $[13]=25 \mu \mathrm{m}$, Scale bars $[9,14,15,16]=200 \mu \mathrm{m}$ Scale bars $[18]=2$ $\mathrm{mm}$. 
Description: Thallus erect, reddish to reddish-brown, fleshy, $7.5-14 \mathrm{~cm}$ high, attached to the substratum by a small discoid holdfast. Thalli flattened, strap-like, with a short basal stipe, up to $1 \mathrm{~cm}$ long, from which arise erect axes 4 - $20 \mathrm{~mm}$ wide, irregularly branched. Specimens robust with dichotomies, or even polytomies, giving them a flabellate aspect. Some branches with cuneate base, 15 - $25 \mathrm{~mm}$ wide. Margins smooth to slightly undulate. Apices rounded, lobed, bifurcate or sometimes cordate. In transverse section, base of thallus with up to 5 layers of ovate to quadrate cortical cells and up to 3 layers of large medullary cells, polygonal in shape to slightly flattened, with thickened walls. Tetrasporangia cruciately divided, scattered on both surfaces of thallus.

Remarks: Gracilariales have a wide geographical distribution, ranging from tropical to polar regions [26]. The order has about nine recognized genera, and their taxonomic history is controversial [27]. The genus Gracilaria Greville is the main source of agarose today [25] and is one of the most species-rich genera within the Rhodophyta. Species of Gracilaria that have a flat morphology are among the most taxonomically challenging taxa due to their phenotypic plasticity among all known species [28].

Several flattened species of Gracilaria have been recorded on the Atlantic coast of Costa Rica: G. cervicornis (Turner) J. Agardh, G. cuneata Areschoug, G. curtissiae J. Agardh and G. domingensis (Kutzing) Sonder ex Dickie. Of these species, only $G$. cuneata shows morphological similarities with $G$. hayi. For the subtropical Western Atlantic G. hayi bears similarities to G. cearensis (A.B. Joly \& F.C. Pinheiro) A.B. Joly \& F.C. Pinheiro, G. galetensis Gurgel, Fredericq \& J. Norris and G. brasiliensis Gurgel \& Yoneshigue-Valentin. Our specimens of Gracilaria hayi are consistent with illustrations and descriptions of G. mammillaris (Montagne) M. Howe made by [29] [30] [31], and with the descriptions of G. cuneata made by [25] [32] [33].

The membranous texture and the crisped margins of the thallus shown by $G$. cuneata set it apart from G. hayi. On the other hand, Gracilaria cearensis has a thinner thallus than that of $G$. hayi, and the latter is more robust than G. galetensis and $G$. brasiliensis. The broad thallus, flabellate appearance, cordate axes, dichotomies in various branching orders, and the absence of marginal proliferations are useful characteristics for the identification of $G$. hayi.

The online information known up to now [24] restricts the distribution of $G$. hayi to Panama, Florida and North Carolina (US) and Brazil. It is very likely that the distribution of this species is much more widespread due to the similarities among flattened species, a fact that often contributes to erroneous identifications due to overlapping diagnostic characters. The identification of only one specimen or young plants can be difficult.

Family: Rhodomelaceae

Bryocladia cuspidata (J. Agardh) De Toni. Sylloge algarum omnium hucusque cognitarum iv .iii: 1903: $968 \equiv$ Polysiphonia cuspidata J. Agardh. Nya alger från Mexico. 1847: 5-17.

Figure 2(3-5). 
Type locality: Veracruz, Mexico [34].

Specimen studied: Voucher MICH: 643966, 1210814 and 1210817.

Habitat: Plants growing on rocks or other massive objects (shells or onto fallen logs) in shallow water, somewhat exposed to wave action. Found from 0 to $0.5 \mathrm{~m}$ deep.

Distribution recorded in Costa Rica: Cahuita, Playa Cocles, Playa Chiquita, Manzanillo, province of Limón.

Description: Thallus between $4-6 \mathrm{~cm}$ in length, purple-red to black coloration; progressively fixed to the substrate by a fibrous structure. Thalli cylindrical, very fibrous and dense with main axes between $200-350 \mu \mathrm{m}$ in width. Thalli are irregularly branched with pinnate branchlets and no secondary branching. Branchlets are rigid and bifurcate at the base, curved towards the main axis. In transverse section, thallus with 6 to 8 pericentral cells. Reproductive structures were not observed.

Remarks: Bryocladia F. Schmitz is a genus with only a few recognized species [24]. Bryocladia is close to Tayloriella; all branches in Tayloriella are said to be exogenously derived, whereas endogenous branchlets are characteristic of Bryocladia. Tayloriella includes four species that are distributed mainly in the Pacific Ocean.

Tayloriella abyssalis, which was described by [35], was later merged with Pterosiphonia hamata, with the current name of Savoiea hamata (Sinova) M.J. Wynne [36]. [37], who described Bryocladia borealis from Pacific Mexico, later transferred the species to Tayloriella, as T. borealis (E. Y Dawson) E. Y [38]. In all known species of Bryocladia the thallus is comprised of prostrate branches, attached by unicellular rhizoids, and erect branches, up to $10 \mathrm{~cm}$ long, having a percurrent axis with few secondary axes. All branches ecorticate, densely clothed with short, determinate, spine-like, exogenous polysiphonous branchlets, spirally arranged, and with up to 12 pericentral cells.

[23] reported Bryocladia thyrsigera (J. Agardh) F. Schmitz and B. cuspidata for the subtropical Western Atlantic. Plants of $B$. thyrsigera arise from a creeping base and have main erect axes to $4-8 \mathrm{~cm}$ tall. They may be somewhat entangled below, sparingly divided, with 10 - 11 pericentral cells, ecorticate, above with numerous shorter branches as much as $2.5 \mathrm{~cm}$ long, bearing pinnate branchlets. These differences are verified at the regional level by [39] when comparing the two species for Venezuela.

The presence of Bryocladia cuspidata is new for the Central American region. The species is very abundant in several localities of the southern Caribbean coast. This differs from the observations made by [40], who considered the species to be uncommon. It is known in the Caribbean region, Florida, Mexico, Cuba, Jamaica, Puerto Rico and other localities in the tropical and subtropical Western Atlantic [23].

Family: Lomentariaceae

Ceratodictyon variabile (J. Agardh) R. E. Norris. S. Afr. J. Bot. 1987: 243. $\equiv$ 
Gelidiopsis variabilis (Greville ex J. Agardh) F. Schmitz. Engler's Bot. Jb.1895: 148.

Figure 2(6-7).

Type locality: Madras, India [41].

Specimen studied: Voucher MICH: 647193, 1210819.

Habitat: common on rocks in the intertidal zone and somewhat lower, particularly in crevices or on overhanging cliffs, often in rather exposed places. Found from 0 to $0.5 \mathrm{~m}$ deep.

Distribution recorded in Costa Rica: Playa Cocles, Manzanillo, province of Limón.

Description: Thallus red to purple, up to $4 \mathrm{~cm}$ high, cartilaginous, very ramified with erect and cylindrical branches, with basal portions prostrate formed by stoloniferous branching. Thalli formed by a cortex of small cells which increase gradually in size inwards where the inner cortex and the medulla are indistinguishable, forming a compact region of larger pseudoparenchymatous cells that are more or less elongated.

Remarks: At present, Ceratodictyon Zanardini is known to include nine species [23]. [42], relocated several species of the genus Gelidiopsis to Ceratodictyon, a genus of red algae in which the stem shape was originally described as reticulated and living in symbiosis with sponges.

By relying on the works of [8] [37] [43], [42] recognized the morphological similarities among the genera Gelidium and Gelidiopsis. Nonetheless, he was able to effectively identify Gelidiopsis variabile as a member of the genus Ceratodictyon.

The taxonomic distinction between Ceratodictyon variabile and C. planicaule (W.R Taylor) M.J. Wynne is controversial in the literature. Both specie s have already been considered synonyms by [42], but the differences observed by [44] [31] justify the maintenance of these two entities as separate species. Ceratodictyon variabile differs from $C$. planicaule in its regular branching and cylindrical thallus all along its anatomy, attributes that were evident in the individuals collected at Playa Cocles and Playa Puerto Viejo. The presence or absence of anastomoses, as well as the width of the thallus and branching pattern, were useful characters for separating the species within the genus.

The presence of Ceratodictyon varibile was previously recorded in Central America: Belize [44], El Salvador [45], Nicaragua [45], and Panama [45]. However, this species is known up to now only from the Pacific coast of Costa Rica [45], although it has a wide distribution worldwide [23].

Phylum: OCHROPHYTA

Class: PHAEOPHYCEAE

Family: Dictyotaceae

Padina boergesenii Allender \& Kraft. Brunonia 1983: 87-88.

Figure 2(8-9).

Type locality: U.S. Virgin Islands, West Indies [46]. 
Specimen studied: Voucher MICH: 637149.

Habitat: Plants often abundant, growing on rocks, old coral, and shells in rather shallow water of moderately protected area. Found from 0.3 to $0.5 \mathrm{~m}$ deep.

Distribution recorded in Costa Rica: Playa Punta Uva, province of Limón.

Description: Thallus 3.5 to $9 \mathrm{~cm}$ in length, $3-4 \mathrm{~cm}$ wide with dark brown coloration. Individuals are attached to the substrate by a basal disc composed of compact rhizoid filaments. Presence of a light calcium carbonate cover on the surface with a conical stipe of between 0.5 to $1 \mathrm{~cm}$ in length. Thalli are laminar, rounded and divided up to three times. The medulla has three rows of cells displayed longitudinally all along the blade except at the apex. These cells are approximately 21 - $30 \mu \mathrm{m}$ wide and $35-45 \mu \mathrm{m}$ in length. They decrease in size as they approach the apical region.

Remarks: The genus Padina Adanson is characterized mainly by having flattened thalli with numerous discoid pheoplasts per cell and fronds with rolled or circinate margins. This second character distinguishes it from the genus Zonaria C. Agardh [47]. The delimitation of Padina specific taxa is generally difficult due to the lack of consistency in literature in regards to the characters that must be taken into account at the species level. The high number of species described for the genus [24] makes the identification of species based solely on morphological characteristics very laborious. The morphology of Padina boergesenii is variable. Individuals growing in continental intertidal zones show divided blades.

Meanwhile, individuals growing in insular intertidal zones show blades with non to slightly divided habits [48]. P. boergesenii is characterized by the presence of two to three layers of cells along the blade, one organized as a layer of medullary cells and two cortical layers. This characteristic construction differentiates the species from others from the tropical Western Atlantic recorded by [23]. According to [49], the character of separation between Padina boergesenii and $P$. gymnospora (Kützing) Sonder is based on the number of cell layers. Padina gymnospora presents three to six layers of cells, while $P$. boergesenii has three along the whole blade (10 [mc]) except the apex (10 [ac]). [48] considered both species to be conspecific, but observations on $P$. boergesenii by [48] allow us to consider this as a different species than $P$. gymnospora.

Furthermore, [49] stated that the holotype of Zonaria gymnospora Kützing presents four layers of cells in the middle portion, and six to eight layers at the base. These authors considered P. gymnospora sensu [50], cited by [8] [51] [52], as a distinct species, namely, $P$. boergesenii. The specimens examined in this study differ from $P$. fraseri (Greville) Greville, a similar species described for Australia. $P$. fraseri has an intermediate layer composed of highly developed central cells, sporangia with a persistent membranous indusium and lines of hair present only in the upper portion of the thallus [53]. Despite the progress in the descriptions made for Padina from the Caribbean, in Latin America (geographical region) the great extent of the studies made for this genus have been made for Pacific species [54]. Recently, it has been evaluated by molecular biology 
techniques with Caribbean species, including $P$. boergesenii [55]. In Central America, it has been recorded only in Panama [56] and the Pacific coast of Costa Rica [57]. Nonetheless, the species is well represented in other geographical regions [24].

Zonaria tournefortii (J. V. Lamouroux) Montagne. Flore d Algérie 1846 [including the generitype $Z$. flava C. Agardh. Synopsis algarum Scandinaviae (1817) as a synonym]

Figure 2(10-11).

Syntype localities: Corsica; southern France; Italy [41].

Specimen studied: Voucher MICH: 640174.

Habitat: Plants on rocks. Found from 3.5 to $8 \mathrm{~m}$ deep.

Distribution recorded in Costa Rica: Playa Punta Uva, province of Limón.

Description: Thallus flattened, with blades up to $10 \mathrm{~cm}$ in length, showing round edges and simple stipes of dark brown coloration without branching. The thallus shows rhizoids comprised of descending filaments that grow and coalesce at different levels and then converge at the base forming a primary axis. In the transverse section the thallus is formed by four strata of medullary cells and a stratum on each side of apical cells.

Remarks: Of the 19 names recognized for the genus Zonaria C. Agardh [24], only $Z$. tournefortii has been recorded for the subtropical Western Atlantic [23]. The structure displayed by the thalli of Zonaria is the result of marginal growth and frequent tears. The morphology varies significantly depending on the age and environmental conditions, such as depth, swell, seasonality, and abrasion to which the thalli are exposed [58] [59]. [60], noted the formation of eight spores in the sporangia and the presence of paraphysis in sporangial sori as distinctive characteristics in Zonaria. Cell division occurs within cell rows, maintaining the strict alignment of cells even in actively growing thallus regions. Thallus thickness and the number of cell layers varies. Except for the thallus margin, thallus thickness increases basipetally although the number of medullary cells does not. In transverse section, the longest dimension of the medullary cells of Zonaria, tends to be parallel to the thallus surface and typically 2 cortical cells overlie each medullary cell (12) Such characters are also present in Lobophora J. Agardh and Stoechospermum Kützing, respectively, along with the arrangement of vertical rows and the size of the spinal cells in both cross and longitudinal sections. Other characteristics such as the presence of one or two cortical cells per spinal cell in cross section, the absence of foot cells in the octosporangia, among others were added by [61]. Costa Rica is the first country in Central America with the presence of Zonaria. However, it is very well distributed in the Mediterranean in countries such as Spain and Italy, as well as in several locations of the subtropical Western Atlantic reaching South East Asia [24].

Family: Sargassaceae

Sargassum furcatum Kütz. Phycol. Gen. 362. 1843. 三 Sargassum vulgare f. furcatum (Kützing) J. Agardh. Species Sargassorum Australiae 1889: 108. 
Figure 2(12-13).

Type locality: St. Thomas, U.S. Virgin Islands, West Indies, [62] failed to state the initials of the collector for the type specimen and only used Ehrenberg as the reference. However, it is subsequently accepted as C. G. Ehrenberg.

Specimen studied: Voucher MICH: 629042, 1210813.

Habitat: Mix of rocky and Sandy substrate, shallow waters. Found from 0 to $1.5 \mathrm{~m}$ deep.

Distribution recorded in Costa Rica: Cahuita, Playa Punta Uva, province of Limón.

Description: Thallus erect to $25 \mathrm{~cm}$ tall, with numerous branches originating from the base area. The attachment base is of up to $1.5 \mathrm{~cm}$ in diameter from which the main branches arise. Branchlets numerous, short, $1-1.5 \mathrm{~cm}$ long, all the axes muricate. Blades are present principally in young parts of thallus, thin, linear-lanceolate, clearly serrulate (toothed), subpercurrent, with a rib, usually dichotomously divided $1-4$ times, $3-4.5 \mathrm{~cm}$ long and $1-1.7 \mathrm{~cm}$ wide, small and large cryptostomata on both sides of the midrib or scattered. Presence of sparse, smooth air-bladders of $3-4 \mathrm{~mm}$ of diameter generally located in the apical portion of the thallus.

Remarks: Currently, the genus Sargassum C. Agardh is recognized to include 358 species [24]. The traditional classification scheme has been based on polymorphic morphological characters (holdfast, axes, phylloids or "leaves", air vesicles and receptacles) is still accepted with some modifications [63]. Variations in the morphology of Sargassum have been clearly documented by several authors [64] [65], and recently proven using molecular techniques [66] [67]. Certain morphological characteristics such as leaves are considered of great utility for the recognition of species, with the shape, length, width, rigidity, margin and surface as the most relevant descriptors. The first four descriptors were considered by [8] [68] for the separation of species in the Western Atlantic. On the other hand, the margin of the leaves was considered to be an unreliable descriptor for species in the Philippines [69], although other authors considered this as a consistent trait to distinguish species in Brazil and Venezuela [64] [68]. Moreover, distinguishing the surface of the leaves either as simple or furrowed is another useful trait for the discrimination of species [8] [31] [40].

Of all the species recorded for Costa Rica [19], S. polyceratium Montagne exhibits the most variation in the morphology of its leaves. These findings are consistent with the results by [70] [71], who found 47 different morphotypes and significant seasonal variability in the morphology of the leaves. This character, however, is very consistent in the specimens of $S$. furcatum examined. Similar findings were described by [64]-[72].

Other species of Sargassum also show this variability in the diagnostic characters for the genus. S. furcatum, for example, was considered a form of $S$. vulgare by two different authors [73] [74]. The presence of receptacles is the most commonly used character in the taxonomy of the genus; however, it cannot be used 
to determine the species.

The size of cryptostomata is a characteristic of relative importance, where it should be considered to separate the specimens based on their state of maturity [64]. Moreover, the arrangement of cryptostomata is highly variable, with their size dependent on that of the leaves [65]. On the other hand, the presence of spines in the branches is a relevant character used for the identification of species in the Caribbean [31]. Also, the diameter and arrangement of the vesicles, although not a key character, helps to distinguish the species.

The spherical vesicles, occasionally hidden under the phylloids, are attributes observed in the $S$. furcatum. No air-bladders were observed in $S$. furcatum in specimens studied in the Gulf of Mexico by [75]. This is the first record in the Central America region, although the species is well distributed in the subtropical western Atlantic [23] and has also been recorded in the Philippines [24].

Phylum: CHLOROPHYTA

Class: ULVOPHYCEAE

Family: Cladophoraceae

Chaetomorpha aerea (Dillwyn) Kütz. Spec. Alg. 379. 1849. $\equiv$ Conferva aerea Dillwyn, Brit. Conferv. 1806: pl. 80. [1802-1809].

Figure 2(14-16).

Type locality: Cromer, Norfolk, England [46].

Specimen studied: Voucher MICH: 70915.

Habitat: Growing on rocks, especially under ledges, in exposed, even surf-beaten locations. Found from 0 to $1.5 \mathrm{~m}$ deep.

Distribution recorded in Costa Rica: Puerto Viejo, Playa Cocles, province of Limón.

Description: Thalli are dark green, with vertical growth of up to $15 \mathrm{~cm}$ in height. They can be solitary or grouped into plumes numerous. Filaments are fixed to the substrate by means of a straight basal cell with rhizoidal extensions at the base that form a lobed disc. These extensions can measure 200 - (400) $1200 \mu \mathrm{m}$ in length, 37.5 - (85) - $130 \mu \mathrm{m}$ in diameter at the base, and 25 - (90) $180 \mu \mathrm{m}$ in diameter at the apex. It has cylindrical suprabasal cells that are between 50 - (160) - $300 \mu \mathrm{m}$ length - 55 - (150) - $200 \mu \mathrm{m}$ in diameter; quadratic to elongated medium-range cells of 70 - (170) - $230 \mu \mathrm{m}$ in length and 87 - (190) $350 \mu \mathrm{m}$ in diameter; filaments with some swollen cells; laminated cell walls, with varying thickness, measuring between 27.5 - (34) - $45 \mu \mathrm{m}$ in the middle region and $10-(13.5)-17.5 \mu \mathrm{m}$ in the apical region; clear constrictions between the septs.

Remarks: At present, Chaetomorpha Kützing has 73 recognized species [24]. It is a cosmopolitan genus, with representatives that can be found in oceanic areas, estuaries and even freshwater. Morphologically it is formed by serial filaments, unbranched, and robust, either erect and attached with an elongate, thick-walled, basal cell or loose-lying. Growth is diffuse, producing cylindrical to barrel-shaped to rarely oval cells 20 - 5000 um in diameter, generally consistent 
within species. One of the most significant characteristics in the delimitation of species within the genus Chaetomorpha is the thickness of the filaments, the stiffness of the thallus and the shape of the segments [76]. According to [77], Chaetomorpha aerea has been treated as a synonym of Chaetomorpha linum (O. F. Müller) Kützing by several authors [43] [78] [79]. [43], considered C. aerea and $C$. linum to be different forms of the same taxon, with the latter name taking precedence. Cytological studies [80] [81], either using morphological attributes [30] [82] [83] [84] or molecular techniques [85], confirmed these as distinct species. The main difference between these taxa is related to the habit. Chaetomorpha linum becomes entangled and is able to form green algal balls [86]. [8], considered that a very distinctive feature in $C$. linum is its ability to form "entangled masses ...". In fact, the Atlantic coast of Costa Rica is listed as one of the localities visited by Taylor. On the other hand, Chaetomorpha aerea grows attached to the substrate using a basal disc and is not a free-form species as $C$. linum.

On the Atlantic coast of Costa Rica, $C$. aerea it is easily differentiated from other species of Chaetomorpha [19] because it has a straight basal cell that measures 200 to $1200 \mu \mathrm{m}$ in length and presents quadratic to cylindrical cells as well as medium apical cells measuring 80 to $350 \mathrm{~mm}$ in diameter. This is a rare species for the area and has been collected only once. This coincides with the report by [31], who also considered C. aerea as a rare species for the Caribbean. For Central America it has been reported only in Belize [44]. Nonetheless it was a worldwide distribution [24].

Class Bryopsidophyceae

Family Bryopsidaceae

Bryopsis pennata J.V. Lamouroux var. secunda (Harvey) Collins \& Hervey. Proc. Amer. Acad. Arts 53.1917: 62.

Bryopsis plumosa (Hudson) C.Agardh var. secunda Harvey. Smithsonian Contrib Knowl. 10 (2). 1858: 31.

Bryopsis harveyana J. Agardh. Acta. Univ. Lund. 23 (2): 22. 1887. According [41] this species is a possible taxonomic or nomenclatural synonym.

Figure 2(17-18).

Syntype localities: Key West and Sand Key, Florida, USA [41].

Specimen studied: Voucher MICH: 1210820, 1210821.

Habitat: Plants of shallows, rather warm and quiet water, growing on woodwork or rock. Found from 0 to $1.5 \mathrm{~m}$ deep.

Distribution recorded in Costa Rica: Puerto Viejo, province of Limón.

Description: Thallus erect formed by coenocytic filamentous appearance, dark green color and a slight iridescence in the water. Fibrous rhizoidal system tightly woven and tightly attached to the substrate. It has branches that extend outward up to 3 to $4 \mathrm{~cm}$ in width from the main axes that do not exceed $300 \mu \mathrm{m}$ in width. The branches show a uniform length ranging from 100 to $150 \mu \mathrm{m}$ in diameter. They are constricted at the base with an angle of approx. $45^{\circ}$ with respect to one another. This arrangement provides the individuals with a unilateral 
arrangement of branches with respect to the main axis.

Remarks: The genus Bryopsis J.V. Lamouroux is described according to the arrangement, length and density of the pinnules, and their arrangement on the main axes of the thallus. Several names have been presented in the literature that for various reasons have been excluded or treated as doubtful (whether not legitimate, invalid publication, synonymous or transferred to other genera [87]. Initially there were only five species described by Lamouroux in 1809 [87]. Currently, a total of 58 species are recognized for the genus [24]. The external characters of morphology and anatomy, couple to reproductive aspects, are key for the identification of species of Bryopsis [88]. The records for Bryopsis for the Atlantic coast of Costa Rica [19] [20], include Bryopsis pennata Lamoroux and Bryopsis pennata var. leprieurii (Kützing) Collins \& Hervey. Bryopsis pennata var. secunda differs from $B$. pennata because the first one presents mostly unilateral branchlets and the frond tends to be one-sided. On the other hand, Bryopsis pennata var. leprieurii has fewer branchlets, which are short, sometimes unilateral in discontinuous series, and with a naked axis.

However, given the phenotypic plasticity resulting from its changes environmental condition, the character states commonly used for the discrimination of entities at the specific level may be misleading [89]. This plasticity in the expression of characters is reinforced by the influence of environmental factors such as temperature and salinity [90] [91]. Although using characteristics of broad phenotypic plasticity may lead to incorrect identifications [92] [93], but are still the most broadly employed characters because reproductive and cytological descriptors are not enough to identify species within Bryopsis. This is the first report of this variety for Central America. However, Bryopsis pennata var. secunda is widespread and can be found in remote regions even within Sub-Antarctic islands [24].

\section{Discussion}

The descriptions for the new records provided in this study contribute to increasing the understanding of floristic diversity of the Caribbean coast of Costa Rica, particularly from its southernmost limit. To date, the number of species described for the country reaches a total of 377 , coinciding with the predictions of [19] [20], who expected the diversity of macroalgae to be higher than what they reported. It should be noted that some new occurrences here described correspond to very conspicuous macroalgae of the families Dictyotaceae and Sargassaceae, which make a considerable contribution to biomass [94].

This study confirms that the area ranging from Cahuita to Manzanillo is the most studied so far in the Caribbean coast of Costa Rica. Still, with these new records, the phycological studies and overall records for the Caribbean remain limited. In part, this reflects the lack of sampling in subtidal areas as well as the costs associated with the logistics to work in the Caribbean coast. The area ranging from Puerto Viejo to Punta Castilla remains the most underexplored 
coastal region in Costa Rica. It is likely that sampling efforts could lead to increasing even more the diversity of macroalgae, and even, other marine species, reported for the Caribbean coast.

For now, our new records provide further data to strengthen the baseline of the floristic richness of Costa Rica. As such, this baseline can be used as a guideline for future ecological or economic studies or can act as a tool to inform policy makers in the development of conservation methods.

\section{Acknowledgements}

The authors thank Dr. Michel J. Wynne for reading the manuscript and adding valuable suggestions for improvement. To Dr. Váleria Cassano, for his useful suggestions to the text. The first author (R. Cabrera) acknowledges the support received during her stay in Costa Rica by the Universidad de Costa Rica (UCR). The authors are grateful to reviewers and editors who helped improve this manuscript with their suggestions.

\section{Conflicts of Interest}

The authors declare no conflicts of interest regarding the publication of this paper.

\section{References}

[1] Fernández-García, C. and Alvarado, J.J. (2008) Chlorophyta of the Pacific Coast of Costa Rica. Revista de Biología Tropical, 56, 149-162.

[2] Fernández-García, C. (2008) Marine Flora of Isla del Coco National Park, Costa Rica, Eastern Tropical Pacific. Revista Biología Tropical, 56, 57-69.

[3] Gutiérrez, J.L., Jones, C.G., Byers, J.E., Arkema, K.K., Berkenbusch, K., Commito, J.A., Duarte, C.M., Hacker, S.D., Lambrinos, J.G., Hendriks, I.E., Hogarth, P.J., Palomo, M.G. and Wild, C. (2011) Physical Ecosystem Engineers and the Functioning of Estuaries and Coasts. In: Wolanski, E. and McLusky, D.S., Eds., Treatise on Estuarine and Coastal Science, Academic Press, Waltham, 53-81. https://doi.org/10.1016/B978-0-12-374711-2.00705-1

[4] Mineur, F., Arenas, F., Assis, J., Davies, A.J., Engelen, A.H., Fernandes, F., Malta, E., Thibaut, T., Nguyen, T.A., Vaz-Pinto, F., Vranken, S., Serrâo, E.A. and De Cleark, O. (2015) European Seaweeds under Pressure: Consequence for Communities and Ecosystem Functioning. Journal of Sea Research, 98, 91-108. https://doi.org/10.1016/j.seares.2014.11.004

[5] Umanzor, S., Ladah, L., Calderon-Aguilera, L.E. and Zertuche-González, J.A. (2019) Testing the Relative Importance of Intertidal Seaweeds as Ecosystem Engineers across Tidal Heights. Journal Experimental Marine Biology and Ecology, 511, 100-107. https://doi.org/10.1016/j.jembe.2018.11.008

[6] Taylor, W.R. (1933) Notes on Algae from the Tropical Atlantic Ocean II. Papers of the Michigan Academy of Science, Arts and Letters, 17, 395-407.

[7] Taylor, W.R. (1942) Caribbean Marine Algae of the Allan Hancock Expedition, 1939. Reports of the Allan Hancock Atlantic Expedition, 2, 1-193.

[8] Taylor, W.R. (1960) Marine Algae of the Eastern Tropical and Subtropical Coasts of the Americas. University of Michigan Press, Ann Arbor, MI, 871 p. 
[9] Dawson, E.Y. (1962) Additions to the Marine Flora of Costa Rica and Nicaragua. Pacific Naturalist, 3, 375-395.

[10] Wellington, G.M. (1973) Additions to the Atlantic Benthic Flora of Costa Rica. Brenesia, 2, 17-20.

[11] Wellington, G.M. (1974) The Benthic Flora of Punta Cahuita: An Annotated List of Species with New Additions to the Costa Rican Atlantic flora. Brenesia, 3, 19-30.

[12] Soto, R. (1983) New Reports for Costa Rica's Benthic Marine Flora. Brenesia, 21, 365-370.

[13] Soto, R. and Ballantine, D.L. (1986) The Marine Benthic Flora of the Caribbean of Costa Rica (Preliminary Notes). Brenesia, 25-26, 123-162.

[14] Kemperman, T.C.M. and Stegenga, H. (1983) The Marine Benthic Algae of the Atlantic Side of Costa Rica. An Annotated, Updated and Enlarged Checklist. Brenesia, 25-26, 99-122.

[15] Thomas, D.T. and Freshwater, D.W. (2001) Studies of Costa Rican Gelidiales (Rhodophyta): Four Caribbean Taxa Including Pterocladiella beachii sp. nov. Phycologia, 40, 340-350. https://doi.org/10.2216/i0031-8884-40-4-340.1

[16] Fernández-García, C. and Alvarado, J.J. (2004) The Coral Reef of Punta Cocles, Caribbean Coast of Costa Rica. Revista de Biología Tropical, 52, 121-129.

[17] Vega-Álvarez, G., Azofeifa-Solano, J.C., Fernández-García, C., Soto-Molinari, R., Rojas-Angulo, M., Amador-Fernández, X. and Vargas-Gamboa, A. (2018) New Records of Benthic Marine Macroalgae from the Caribbean Coast of Costa Rica. Revista Biología Tropical, 66, 328-339. https://doi.org/10.15517/rbt.v66i1.33302

[18] Camacho, O., Fernández-García, C., Vieira, C., Gurgel, C.F.D., Norris, J.N., Freshwater, D.W. and Fredericq, S. (2019) The Systematics of Lobophora (Dictyoyales, Phaeophyceae) in the Western Atlantic and Eastern Pacific Oceans: Eight New Species. Journal of Phycology, 55, 611-624. https://doi.org/10.1111/jpy.12850

[19] Bernecker, A. (2009) Marine Benthic Algae. In: Wehrtmann, I.S. and Cortés, J., Eds., Marine Biodiversity of Costa Rica, Central America, Springer Science + Business Media B.V., Berlin, Germany, 109-117. https://doi.org/10.1007/978-1-4020-8278-8 5

[20] Bernecker, A. and Wehrtmann, I.S. (2009) New Records of Benthic Marine Algae and Cyanobacteria for Costa Rica, and a Comparison with Other Central American Countries. Helgoland Marine Research, 63, 219-222. https://doi.org/10.1007/s10152-009-0151-1

[21] Mairena, G. and Vindas, J. (2009) Potable Water and Rural Basic Sanitation Program II A y A-KfW. Hidrogénesis, 7, 9-14.

[22] Portugal, A.B., Carvalho, F.L., Carneiro, P.B.M., Rossi, S. and Soares, M.O. (2016) Increased Anthropogenic Pressure Decreases Species Richness in Tropical Intertidal Reefs. Marine Environmental Research, 120, 44-54. https://doi.org/10.1016/j.marenvres.2016.07.005

[23] Wynne, M.J. (2017) A Checklist of Benthic Marine Algae of the Tropical and Subtropical Western Atlantic: Fourth Revision. Nova Hedwigia, 145, 1-202.

[24] Guiry, M.D. and Guiry, G.M. (2019) AlgaeBase. World-Wide Electronic Publication, National University of Ireland, Galway. http://www.algaebase.org

[25] Soares, L.P., Gurgel, C.F.D. and Fujii, M.T. (2018) Gracilaria suzannae sp. nov. (Gracilariales, Rhodophyta), a New Flattened Species from Northeast Brazil Based on Morphological and Molecular Evidence. Phycologia, 57, 345-353.

https://doi.org/10.2216/17-102.1 
[26] Gurgel, C.F.D., Norris, J.N., Schmidt, W.E., Le, H.N. and Fredericq, S. (2018) Systematics of the Gracilariales (Rhodophyta) including New Subfamilies, Tribes, Subgenera, and Two New Genera, Agarophyton gen. nov. and Crassa gen. nov. Phytotaxa, 374, 1-23. https://doi.org/10.11646/phytotaxa.374.1.1

[27] Gurgel, C.F.D., Fredericq, S. and Norris, J.N. (2004) Molecular Systematics and Taxonomy of Flattened Species of Gracilaria Greville (Gracilariaceae, Gracilariales, Rhodophyta) from the Western Atlantic. In: Abbott, I.A. and McDermid, K.J., Eds., Taxonomy of Economic Seaweeds, with Reference to the Pacific and Other locations, Hawaii Sea Grant College Program, University of Hawaii, Honolulu, HI, 159-199.

[28] Soares, L.P., Gurgel, C.F.D. and Fuji, M.T. (2015) Taxonomic Reassessment of Gracilaria cearensis (Rhodophyta, Gracilariales), a Poorly Defined yet Common Flattened Species Based on Morphological and Molecular Analysis including Topotype Collections. Phytotaxa, 201, 241-255. https://doi.org/10.11646/phytotaxa.201.4.1

[29] Schneider, C.W. (1975) Taxonomic Notes on Gracilaria mammillaris (Mont.) Howe and Gracilaria veleroae Dawson (Rhodophyta, Gigartinales). Taxon, 24, 643-646. https://doi.org/10.2307/1220737

[30] Schneider, C.W. and Searles, R.B. (1991) Seaweeds of Southeastern United States: Cape Hatteras to Cape Canaveral. Duke University Press, Durham. https://doi.org/10.1215/9780822397984

[31] Littler, D.S. and Littler, M.M. (2000) Caribbean Reef Plants. An Identification Guide to the Reef Plants of the Caribbean, Bahamas, Florida and Gulf of Mexico. Off Shore Graphics, Washington DC, $542 \mathrm{p}$.

[32] Hay, M.E. and Norris, J.N. (1984) Seasonal Reproduction and Abundance of Six Sympatric Species of Gracilaria Grev. (Gracilariaceae; Rhodophyta) on a Caribbean Subtidal Sand Plain. In: Bird, C.J. and Ragan, M.A., Eds., Eleventh International Seaweed Symposium. Developments in Hydrobiology, Springer, Dordrecht, 63-72. https://doi.org/10.1007/978-94-009-6560-7 10

[33] Dawes, C.J. and Mathieson, A.C. (2008) The Seaweeds of Florida. University Press of Florida, Gainesville, FL, $8+592$ p.

[34] Agardh, J.G. (1847) Nya alger från Mexico. Öfversigt af Kongl. Vetenskaps-Adademiens Förhandlingar, Stockholm, 4, 5-17.

[35] Wynne, M.J. (1985) Two New Species of Tayloriella (Rhodomelaceae, Rhodophyta) from the Northeastern North Pacific. Journal of Phycology, 21, 107-114. https://doi.org/10.1111/j.0022-3646.1985.00107.x

[36] Wynne, M.J. (2018) The Status of Polyostea Ruprecht (1850) and the Proposal of Savoieagen. nov. (Rhodomelaceae, Rhodophyta). Notulae Algarum, 69, 1-4.

[37] Dawson, E.Y. $(1954,1953)$ Notes on Pacific Coast Marine Algae. VI. Wasmann Journal of Biology, 11, 323-351.

[38] Dawson, E.Y. (1963) Marine Red Algae of Pacific Mexico. Part 8. Ceramiales: Dasyaceae, Rhodomelaceae. Nova Hedwigia, 6, 401-481 + 126-171.

[39] Solé, M. and Pardo, P. (2010) Marine Ficoflora from the South of the Macanao Peninsula, Margarita Island, Venezuela: II. Rhodophyta. Acta Botánica Venezuelica, 33, 187-211.

[40] Littler, D.S., Littler, M.M. and Hanisak, M.D. (2008) Submersed Plants of the Indian River Lagoon. A Floristic Inventory and Field Guide. OffShore Graphics, Inc., Washington DC, 285 p. 
[41] Silva, P.C., Basson, P.W. and Moe, R.L. (1996) Catalogue of the Benthic Marine Algae of the Indian Ocean. University of California Publications in Botany, 79, 1-1259.

[42] Norris, R.E. (1987) The Systematic Position of Gelidiopsis and Ceratodictyon (Gigartinales, Rhodophyceae), Genera New to South Africa. South African Journal of Botany, 53, 239-246. https://doi.org/10.1016/S0254-6299(16)31436-3

[43] Lawson, G.W. and John, D.W. (1982) The Marine Algae and Coastal Environment of Tropical West Africa. Beihefte zur. Nova Hedwigia, 70, 1-445.

[44] Littler, D.S. and Littler, M.M. (1997) An Illustrated Marine Flora of the Pelican Cays, Belize. Bulletin of the Biological Society of Washington, 9, 1-149.

[45] Fernández-García, C., Riosmena-Rodríguez, R., Wysor, B., Tejada, O.L. and Cortéz, J. (2011) Checklist of the Pacific Marine Macroalgae of Central America. Botanica Marina, 54, 53-73. https://doi.org/10.1515/bot.2011.001

[46] Lipkin, Y. and Silva, P.C. (2002) Marine Algae and Seagrasses of the Dahlak Archipelago, Southern Red Sea. Nova Hedwigia, 75, 1-90. https://doi.org/10.1127/0029-5035/2002/0075-0001

[47] Nunes, J.M. and de Paula, E.J. (2000) Taxonomic Study of the Genus Padina Adason (Dictyotaceae Phaephyta) Not Coastal of the State of Bahia, Brazil. Acta Botanica Matacitana, 25, 21-43.

[48] Ávila-Ortiz, A.G., Mateo-Cid, L.E. and Mendoza-González, A.C. (2011) Morphological Characterization of Padina Boergesenii (Dictyotaceae, Phaeophyceae) on the Mexican Coast of the Gulf of Mexico and the Caribbean Sea. Polibotánica, 31, 1-20.

[49] Allender, B.M. and Kraft, G.T. (1983) The Marine Algae of Lord Howe Island (New South Wales): The Dictyotales and Cutleriales (Phaeophyta). Brunonia, 6, 73-130. https://doi.org/10.1071/BRU9830073

[50] Vickers, A. (1905) Liste des algues marines de la Barbade. Annales des sciences naturelles. Botanique et biologie végétale, 9, 45-66.

[51] Børgesen, F. $(1913,1914)$ The Marine Algae of the Danish West Indies. II. Phaeophyceae. Dansk botanisk arkiv, 2, 1-66. https://doi.org/10.5962/bhl.title.1314

[52] Earle, S. (1968) Phaeophyta of the Eastern Gulf of Mexico. Phycologia, 7, 71-254. https://doi.org/10.2216/i0031-8884-7-2-71.1

[53] Womersley, H.B.S. (1967) A Critical Survey of the Marine Algae of Southern Australia. II. Phaeophyta. Australian Journal of Botany, 15, 189-270. https://doi.org/10.1071/BT9670189

[54] Ávila-Ortiz, A.G. and Pedroche, F.P. (2005) The Genus Padina (Dictyotaceae, Phaeophyceae) in the Tropical Region of the Mexican Pacific. Monografías Ficológicas, 2, 139-171.

[55] Díaz-Martínez, S., Zuccarello, G.C., Salazar Chávez, G.A., Pedroche, F.F. and Ávila-Ortiz, A.G. (2016) Species of Padina (Dictyotales, Phaeophyceae) in Tropical Mexican Waters Based on Molecular-Assisted Taxonomy. Phycologia, 55, 673-687. https://doi.org/10.2216/16-15.1

[56] Wysor, B. and De Clerck, O. (2003) An Updated and Annotated List of Marine Brown Algae (Phaeophyceae) of the Caribbean Coast of the Republic of Panama. Botanica Marina, 46, 151-160. https://doi.org/10.1515/BOT.2003.016

[57] Steen, F., Vieira, C., Leliaert, F., Payri, E.C. and De Clerck, O. (2015) Biogeographic Affinities of Dictyotales from Madagascar: A Phylogenetic Approach. Cryptogamie Algologie, 36, 129-141. https://doi.org/10.7872/crya.v36.iss2.2015.129 
[58] Montañez, A., Sansón, M. and Reyes, J. (2004) Analysis of the Landslides of Zonaria tournefortii in the North of Tenerife: Density, Length, Coverage and biomass of the Different Phases of Its Life Cycle (Dictyotales, Phaeophyta). Vieraea, 32, 151-165.

[59] Ballantine, D.L., Ruíz, H. and Norris, J.N. (2015) Notes on the Benthic Marine Algae of Puerto Rico, XI: New Records Including New Meredithia (Kallymeniaceae, Rhodophyta) Species. Botanica Marina, 58, 355-365.

https://doi.org/10.1515/bot-2015-0005

[60] Papenfuss, G.F. (1977) Review of Genera of Dictyotales (Phaeophyta). Bulletin Japonese Society of Phycology, 25, 271-287.

[61] Phillips, J.A. (1997) Genus and Concepts in Zonaria and Homeostrichus (Dictyotales, Phaeophyceae), including the Description of Exallosorus gen. nov. European Journal of Phycology, 32, 303-311. https://doi.org/10.1080/09670269710001737229

[62] Kützing, F.T. (1843) Phycologia generalis: Oder Anatomie, Physiologie und Systemkunde der Tange. Mit 80 farbig gedruckten Tafeln, gezeichnet und gravirt vom Verfasser. F.A. Brockhaus, Leipzig, Part 1: 1-57, 1-142, Part 2, 143-458. https://doi.org/10.5962/bhl.title.4746

[63] Yoshida, T., Ajiksaka, T., Noro, T., and Horiguchi, T. (2004) Species of the Genus Sargassum Subgenus Schizophycus. In: Abbott, I.A. and McDermid, K., Eds., Taxonomy of Economic Seaweeds with Reference to the Pacific and Other Locations, IX, Hawaii Sea Grant College, La Jolla, CA, Article No. 93106.

[64] Paula, E.J. (1988) The Genus Sargassum C. Ag. (Phaeophyta-Fucales) of Coastal of the State of Sao Paulo, Brazil. Boletim de Botanica da Universidade de Sao Paulo, 10, 65-118. https://doi.org/10.11606/issn.2316-9052.v10i0p65-118

[65] Kilar, J.A., Hanisak, M.D. and Yoshida, T. (1992) On the Expression of Phenotypic Variability: Why Is Sargassum so Taxonomically Difficult? In: Abbott, I.A., Ed., Taxonomy of Economic Seaweeds. with Reference to Some Pacific and Western Atlantic Species, California Sea Grant College, La Jolla, CA, 95-117.

[66] Mattio, L. and Payri, C.E. (2011) 190 Years of Sargassum Taxonomy, Facing the Advent of DNA Phylogenies. The Botanical Review, 77, 31-70. https://doi.org/10.1007/s12229-010-9060-x

[67] Camacho, O., Mattio, L., Draisma, S.F. and Diaz-Pulido, G. (2015) Morphological and Molecular Assessment of Sargassum (Fucales, Phaeophyceae) from Caribbean Colombia, Including the Proposal of Sargassum giganteum sp. nov., Sargassum schnetteri comb. nov. and Sargassum Section Cladophyllum sect. nov. Systematics and Biodiversity, 13, 105-130. https://doi.org/10.1080/14772000.2014.972478

[68] Bertossi, A. and Ganesan, E.K. (1973) The Genus Sargassum C. Agardh (Phaeophyceae) in Eastern Venezuela. Lagena, 31, 3-22.

[69] Ang Jr., P.O. and Trono Jr., G.C. (1987) The Genus Sargassum (Phaeophyta, Sargassaceae) from Balibago, Calatagan, Philippines. Botanica Marina, 30, 387-397. https://doi.org/10.1515/botm.1987.30.5.387

[70] Kilar, J.A. and Hanisak, D. (1988) Seasonal Patterns of Morphological Variability in Sargassum polyceratium (Phaeophyta). Journal of Phycology, 24, 467-473. https://doi.org/10.1111/j.1529-8817.1988.tb04249.x

[71] Kilar, J.A. and Hanisak, D. (1989) Phenotypic Variability in Sargassum polyceratium (Fucales, Phaeophyta). Phycologia, 28, 491-500. https://doi.org/10.2216/i0031-8884-28-4-491.1

[72] Moreira, L. and Suárez, A.M. (2002) Study of the Genus Sargassum C. Agardh, 1820 (Phaeophyta, Fucales, Sargassaceae) in Cuban Waters. 1. Sargassum furcatum Kützing, 1843, New Record. Revista de Investigaciones Marinas, 23, 53-54. 
[73] Børgesen, F. (1914) The Species of Sargassum, Found along the Coast of the Danish West Indies, with Remarks upon the Floating Forms of the Sargasso Sea. In: Anledning af Hundredaared af Japetus Steenstrups Fødsel, 1-20 p.

[74] Grunow, A. (1916) Additamenta ad cognitionem Sargassorum. In: Verhandlungen der Kaiserlich-Königlichen Zoologisch-Botanischen Gesellschaft in Wien, Zoologisch-Botanische Gesellschaft, Wien, 1-148+136-185.

[75] Robinson, N.M., Galicia-García, C. and Okolodkov, Y.B. (2012) New Records of Green (Chlorophyta) and Brown Algae (Phaeophyceae) for Cabezo Reef, National Park Sistema Arrecifal Veracruzano, Gulf of Mexico. Acta Botanica Mexicana, 101, 11-48. https://doi.org/10.21829/abm101.2012.24

[76] Wynne. M.J. (2011) Proposal of the Name Chaetomorpha vieillardii Kützing, nov. Comb., for a Large-Celled Tropical Chaetomorpha (Chlorophyta). Pacific Science, 65, 109-115. https://doi.org/10.2984/65.1.109

[77] Mystikou, A., Aseni, A.O., DeClerck, O., Müller, D.G., Peters, A.F., Tsiamis, K., Fletcher, K.I., Westermeier, R., Brickle, P., van West, P. and Küpper, F.C. (2016) New Records and Observations of Macroalgae and Associated Pathogens from the Falkland Islands, Patagonia and Tierra del Fuego. Botanica Marina, 59, 105-121.

[78] Kapraun, D.F. (1984) An Illustrated Guide to the Benthic Marine Algae of Coastal North Carolina. II. Chlorophyta and Phaeophyta. Bibliotheca Phycologica, 58, 1173.

[79] Burrows, E.M. (1991) Seaweeds of the British Isles. Volume 2. Chlorophyta. Natural History Museum Publications, London.

[80] Sinha, J.P. (1958) Chromosome Numbers and Life Cycles in Members of Cladophorales. British Phycological Journal, 1, 24-27.

[81] Patel, R.J. (1971) Cytotaxonomical Studies on Chaetomorpha linum (O. F. Müll.) Kütz. and C. aerea (Dillwyn) Kütz. Phykos. Journal of the Phycological Society, 11, $17-22$.

[82] Nizamuddin, M. and Begum, M. (1973) Revision of the Marine Cladophorales from Karachi. Botanica Marina, 16, 1-18. https://doi.org/10.1515/botm.1973.16.1.1

[83] Rull Lluch, J. (2002) Marine Benthic Algae of Namibia. Scientia Marina, 66, 5-256. https://doi.org/10.3989/scimar.2002.66s35

[84] Alvez, A.M., Wallace do Nascimento, C., Limoeiro, G. and De Souza, L.M. (2009) Os gêneros Chaetomorpha Kütz. nom. cons. e Rhizoclonium Kütz. (Chlorophyta) do litoral do Estado da Bahia, Brasil. Revista Brasileira de Botânica, 32, 545-570. https://doi.org/10.1590/S0100-84042009000300014

[85] Bingxin, H., Linhong, T. and Lanping, D. (2016) Morphological and Molecular Discrimination of Green Macroalgae Chaetomorpha aerea and C. linum. Acta Oceanologica Sinica, 35, 118-123. https://doi.org/10.1007/s13131-016-0841-x

[86] Cooke, J., Lanfear, R., Downing, A., Gillings, M.R., Poore, A.G.B., Goodwin, I.D., Waldron, L.S., Yola Metti, A.P and Bulbert, M.W. (2015) The Unusual Occurrence of Green Algal Balls of Chaetomorpha linum on a Beach in Sydney, Australia. Botanica Marina, 58, 401-407. https://doi.org/10.1515/bot-2015-0061

[87] Wynne, M.J. (2005) Two New Species of Bryopsis (Ulvophyceae, Chlorophyta) from the Sultanate of Oman, with a Census of Currently Recognized Species in the Genus. Contributions from the University of Michigan Herbarium, 24, 229-256.

[88] Hillis-Colinvaux, L. (1984) Systematics of the Siphonales. In: Irvine, D.E.G. and John, D.M., Eds., Systematics of the Green Algae. The Systematics Association Special, Academic Press, New York, 271-296 + 330-339.

[89] Woolcott, G.W., Knöller, K. and King, R.J. (2000) Phylogeny of the Bryopsidaceae 
(Bryopsidales, Chlorophyta): Cladistic Analyses of Morphological and Molecular Data. Phycologia, 39, 471-481. https://doi.org/10.2216/i0031-8884-39-6-471.1

[90] Silva, P.C. (1979) The Benthic Algal Flora of Central San Francisco Bay. In: Conomos, T.J., Ed., San Francisco Bay: The Urbanized Estuary Pacific Division, American Association for the advancement, San Francisco, CA, 287-345.

[91] Krellwitz, E.C., Kowallik, K.V. and Manos, P.S. (2001) Molecular and Morphological Analyses of Bryopsis (Bryopsidales, Chlorophyta) from the Western North Atlantic and Caribbean. Phycologia, 40, 330-339.

https://doi.org/10.2216/i0031-8884-40-4-330.1

[92] Kapraun, D.F. (2005) Nuclear DNA Content Estimates in Multicellular Green, Red and Brown Algae: Phylogenetic Considerations. Annals of Botany, 95, 7-44. https://doi.org/10.1093/aob/mci002

[93] Tufiño-Velázquez, R.C. and Pedroche, F.F. (2019) Species of the Genus Bryopsis (Chlorophyta) on the Atlantic Coasts of Mexico. Revista Mexicana de Biodiversidad, 90, 1-12. https://doi.org/10.22201/ib.20078706e.2019.90.2679

[94] Kinzie, R.A. (2008) Four Decades of Macroalgal Stasis and Change on an Urban Coral Reef. Micronesica, 40, 101-122. 